Article

\title{
Triterpenic Acids from Eugenia moraviana
}

\author{
Inês Lunardi, Juliana L. B. Peixoto, Cleuza C. da Silva, Ivânia T. A. Shuquel, \\ Ernani A. Basso and Gentil J. Vidotti*
}

Departamento de Química, Universidade Estadual de Maringá, Av. Colombo, 5790, 87020-900, Maringá - PR, Brazil.

\begin{abstract}
Um novo triterpeno caracterizado como ácido $6 \alpha$-hidroxibetulínico foi isolado das folhas e caule da planta, vulgarmente conhecida no Brasil como Cambuí, Eugenia moraviana (Myrtaceae), juntamente com três outras substâncias conhecidas, identificadas como ácido platânico, ácido betulínico

$\beta$-sitosterol. Através da análise de espectros incluindo NOE e experimentos de RMN em duas dimensões foi realizada a atribuição inequívoca dos deslocamentos químicos de ${ }^{1} \mathrm{H}$ e de ${ }^{13} \mathrm{C}$ do

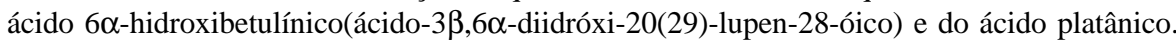

A novel triterpene, characterized as $6 \alpha$-hydroxybetulinic acid, was isolated from the leaves and stems of Eugenia moraviana (Myrtaceae), known in Brazil as Cambuí, together with three known compounds, platanic acid, betulinic acid and $\beta$-sitosterol. Unequivocal ${ }^{1} \mathrm{H}$ and ${ }^{13} \mathrm{C}$ assignments of $6 \alpha$-hydroxybetulinic acid (3 $\beta, 6 \alpha$-dihydroxy-20(29)-lupen-28-oic acid) and platanic acid were undertaken by spectral analysis including NOE and 2 D NMR experiments.

Keywords: Eugenia moraviana, $6 \alpha$-hydroxybetulinic acid, platanic acid, betulinic acid

\section{Introduction}

Eugenia moraviana Berg. (Myrtaceae) is a tree that occurs in South America, mainly in Brazil, Argentina and Paraguai ${ }^{1}$. The leaves of some Eugenia species are used in folk medicine for several therapeutics finalities ${ }^{2,3}$. Compounds such as flavonoids, triterpenes, tannins and especially essential oils constituted of monoterpenes and sesquiterpenes have already been isolated from the genus Eugenia $^{4-6}$. However, no reports were found on the Eugenia moraviana constituents. Our phytochemical studies on the leaves and stems of E. moraviana resulted in the isolation of a new lupane-type triterpenoid, which was characterized as $6 \alpha$-hydroxybetulinic acid (1) together with three known compounds identified as platanic acid (2), betulinic acid and $\beta$-sitosterol ${ }^{7}$. Compound 2 and betulinic acid have been attracting much attention in natural products chemistry because they present biological activities, e.g. anti-HIV ${ }^{8}$, antitumor promoter ${ }^{9}$, antimalarial and anti-inflammatory activities ${ }^{10,11}$. Previous assignments of ${ }^{13} \mathrm{C}$ signals $8,12,13$ led to divergence between the $\mathrm{C}-18$ and $\mathrm{C}-19$ chemical shifts of compounds 1 and 2 and also between the C-15 and C-21 chemical shifts of $\mathbf{2}$. In the present study we used techniques like COSY, HETCOR, HETCORLR and NOE difference,

*e-mail: gjvidotti@uem.br acquired at $300 \mathrm{MHz}\left({ }^{1} \mathrm{H}\right)$, to report an unequivocal and complete ${ }^{1} \mathrm{H}$ and ${ }^{13} \mathrm{C}$ assignment of compounds $\mathbf{1}$ and $\mathbf{2}$. Peng and cols ${ }^{14}$ reported the betulinic acid resonance assignment through a combination of high resolution NMR spectroscopy and a computer-assisted structure elucidation expert system. The authors run ${ }^{13} \mathrm{C} / \mathrm{DEPT}$, DQF COSY, HMBC, HMQC and NOESY spectra, acquired with a 720 $\mathrm{MHz}\left({ }^{1} \mathrm{H}\right)$ spectrometer.

\section{Results and Discussion}

Structural elucidation and NMR signal assignments of $6 \alpha$-hydroxybetulinic acid (1)

Compound 1, mp $285-288{ }^{\circ} \mathrm{C}$; was isolated as white crystals. Its EIMS spectrum showed a molecular peak $[\mathrm{M}]^{+\bullet}$ at $\mathrm{m} / \mathrm{z} 472$ corresponding to the formula $\mathrm{C}_{30} \mathrm{H}_{48} \mathrm{O}_{4}$ and other peaks at m/z 248, 203, 187 and 175, which are characteristic for a pentacyclic triterpene skeleton of the lupane series ${ }^{15}$. The IR spectrum showed absorptions due to hydroxyl (3454 $\left.\mathrm{cm}^{-1}\right)$, carboxyl $\left(1685 \mathrm{~cm}^{-1}\right)$ and exo-methylene (1639 and $\left.879 \mathrm{~cm}^{-1}\right)$ groups. The complete and unequivocal ${ }^{1} \mathrm{H}$ and ${ }^{13} \mathrm{C}$ chemical shifts assignments of 1 were assisted by DEPT, COSY $\left({ }^{1} \mathrm{H} \mathrm{x}{ }^{1} \mathrm{H}\right)$, HETCOR $\left({ }^{13} \mathrm{C}{ }^{1} \mathrm{H}\right)$ and HETCORLR $\left({ }^{13} \mathrm{C} \mathrm{x}{ }^{1} \mathrm{H}\right)$ spectra (Table 1$)$. The ${ }^{13} \mathrm{C}$ NMR spectral data of 1 were compared with those from $6 \beta$-hydroxybetulinic acid $^{16}$. According to our results the $\mathrm{C}-17$ was erroneously 
assigned and the C-15/C-21 and C-18/C-19 were interchanged. The antiperiplanar coupling $\left(J_{6,7 \mathrm{a}}\right.$ and $\left.J_{6,5 \mathrm{a}}\right)$ of $10.4 \mathrm{~Hz}$ and the synclinal coupling $\left(J_{6,7 \mathrm{e}}\right)$ of $3.8 \mathrm{~Hz}$ for H-6 proton at $\delta 4.35$, indicated that the hydroxyl group at C-6 is $\alpha$-orientation. The NOE difference NMR experiment was also performed to confirm the hydroxyl group orientation at C-6. Irradiation of the H-6 signal at $\delta 4.35$ produced an enhancement in the methyl protons resonances at $\delta 1.45(\mathrm{H}-24,5.0 \%), 0.96(\mathrm{H}-25,6.5 \%)$ and $1.19(\mathrm{H}-26$, $5.9 \%$, which reveals a coaxial relationship between $\mathrm{H}-6$, $\mathrm{H}-24, \mathrm{H}-25$ and $\mathrm{H}-26$ thus confirming the equatorial position of the hydroxyl group at C-6. According to the observed NOE enhancements the structure of compound 1 should be as shown in Figure 1.

Assignments of C-15, C-18, C-19 and C-21

in the platanic acid (2)

To unequivocally assign carbons $15,18,19$ and 21 in compound 2 the NOE difference spectra and a HETCOR spectrum were obtained. Initially the proton at $\delta 3.71$ was irradiated and a NOE enhancement was observed at $\delta 2.24$ $(\mathrm{H}-29)$. Irradiation of the signal at $\delta 2.40$ provided NOE enhancements at $\delta 1.61(\mathrm{Ha}-16)$ and $1.10(\mathrm{H}-27)$.

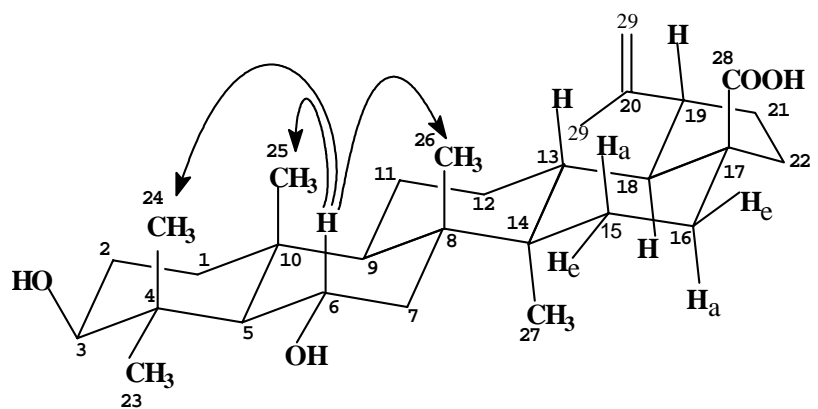

Figure 1. Schematic representation of selected NOE difference spectroscopy of $\mathbf{1}$.

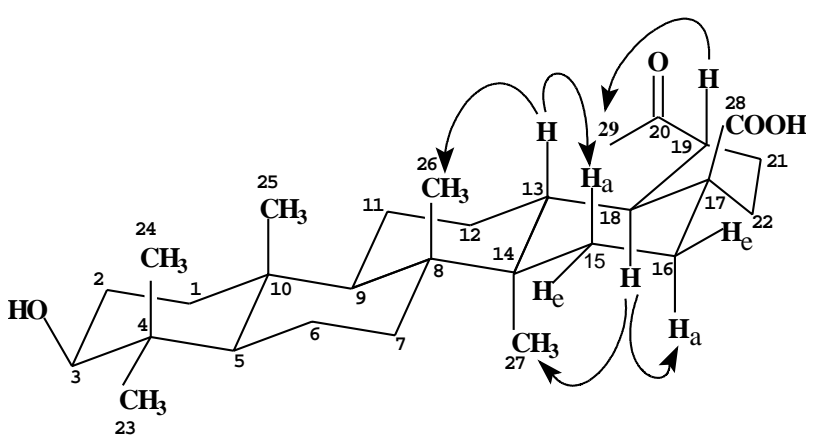

Figure 2. Schematic representation of selected NOE difference spectroscopy of $\mathbf{2}$.

Table 1. ${ }^{13} \mathrm{C}^{\mathrm{a}}(75.5 \mathrm{MHz})$ and $2 \mathrm{D}$ NMR data of $6 \alpha$-hydroxybetulinic acid (1) in pyridine- $\mathrm{d}_{5}$

\begin{tabular}{|c|c|c|c|c|c|}
\hline $\mathrm{C}$ & $\delta^{13} \mathrm{C}^{\mathrm{b}}$ & $\delta^{13} \mathrm{C}(\mathrm{DEPT})$ & $\begin{array}{c}\text { HETCOR } \\
\left({ }^{13} \mathrm{Cx}^{1} \mathrm{H}\right) \delta^{1} \mathrm{H}\end{array}$ & $\begin{array}{c}\operatorname{COSY}\left({ }^{1} \mathrm{Hx}^{1} \mathrm{H}\right) \\
\left({ }^{2} J,{ }^{3} J \text { and }{ }^{4} J\right)\end{array}$ & $\begin{array}{l}\text { HETCORLR } \\
\left({ }^{2} J \text { and }{ }^{3} J\right)\end{array}$ \\
\hline 1 & $38.7\left(\mathrm{CH}_{2}\right)$ & $39.3\left(\mathrm{CH}_{2}\right)$ & $1.10 ; 1.70$ & $1.70 ; 1.10 ; 1.90$ & 0.96 \\
\hline 2 & $27.3\left(\mathrm{CH}_{2}\right)$ & $28.2\left(\mathrm{CH}_{2}\right)$ & 1.90 & 1.10 & \\
\hline 3 & $78.9(\mathrm{CH})$ & $78.7(\mathrm{CH})$ & 3.60 & 2.01 & \\
\hline 4 & 38.9 (C) & $40.4(\mathrm{C})$ & - & & $1.45 ; 2.01\left({ }^{2} \mathrm{~J}\right)$ \\
\hline 5 & $57.1(\mathrm{CH})$ & $61.4(\mathrm{CH})$ & 1.23 & 4.35 & $0.96 ; 1.45 ; 1.70 ; 2.01$ \\
\hline 6 & $69.6(\mathrm{CH})$ & $67.9(\mathrm{CH})$ & 4.35 & $1.23 ; 1.99$ & \\
\hline 7 & $42.6\left(\mathrm{CH}_{2}\right)$ & $47.5\left(\mathrm{CH}_{2}\right)$ & 1.99 & 4.35 & 1.19 \\
\hline 8 & 40.7 (C) & $42.3(\mathrm{C})^{2}$ & - & & $1.19\left({ }^{2} \mathbf{J}\right)$ \\
\hline 9 & $50.4(\mathrm{CH})$ & $50.7(\mathrm{CH})$ & 1.51 & & $0.96 ; 1.19$ \\
\hline 10 & $37.2(\mathrm{C})$ & 39.6 (C) & - & & \\
\hline 11 & $21.2\left(\mathrm{CH}_{2}\right)$ & $21.2\left(\mathrm{CH}_{2}\right)$ & $1.19 ; 1.48$ & $1.48 ; 1.19 ; 1.98$ & \\
\hline 12 & $25.6\left(\mathrm{CH}_{2}\right)$ & $26.2\left(\mathrm{CH}_{2}\right)$ & $1.27 ; 1.98$ & 1.19 & \\
\hline 13 & $38.5(\mathrm{CH})$ & $38.3(\mathrm{CH})$ & 2.75 & & 1.11 \\
\hline 14 & 42.3 (C) & $43.0(\mathrm{C})$ & - & & $2.61 ; 1.19$ \\
\hline 15 & $30.6\left(\mathrm{CH}_{2}\right)$ & $30.4\left(\mathrm{CH}_{2}\right)$ & $1.31 ; 1.93$ & & 1.11 \\
\hline 16 & $29.3\left(\mathrm{CH}_{2}\right)$ & $32.9\left(\mathrm{CH}_{2}\right)$ & $1.57 ; 2.61$ & $2.61 ; 1.57$ & \\
\hline 17 & $48.0(\mathrm{C})$ & $56.7(\mathrm{C})$ & - & & 1.31 \\
\hline 18 & $48.0(\mathrm{CH})$ & $49.8(\mathrm{CH})$ & 1.76 & 3.55 & 2.61 \\
\hline 19 & $48.8(\mathrm{CH})$ & $47.8(\mathrm{CH})$ & 3.55 & 1.76 & \\
\hline 20 & 150.7 (C) & $151.5(\mathrm{C})$ & - & & $1.80\left({ }^{2} \mathrm{~J}\right)$ \\
\hline 21 & $30.0\left(\mathrm{CH}_{2}\right)$ & $31.2\left(\mathrm{CH}_{2}\right)$ & $1.53 ; 2.23$ & & \\
\hline 22 & $34.0\left(\mathrm{CH}_{2}\right)$ & $37.7\left(\mathrm{CH}_{2}\right)$ & $1.59 ; 2.27$ & $2.27 ; 1.59$ & \\
\hline 23 & $28.0\left(\mathrm{CH}_{3}\right)$ & $32.1\left(\mathrm{CH}_{3}\right)$ & 2.01 & $3.60 ; 1.45$ & 1.45 \\
\hline 24 & $16.2\left(\mathrm{CH}_{3}\right)$ & $16.6\left(\mathrm{CH}_{3}\right)$ & 1.45 & 2.01 & $2.01 ; 1.23$ \\
\hline 25 & $16.8\left(\mathrm{CH}_{3}\right)$ & $17.6\left(\mathrm{CH}_{3}\right)$ & 0.96 & & \\
\hline 26 & $18.7\left(\mathrm{CH}_{3}\right)$ & $18.0\left(\mathrm{CH}_{3}\right)$ & 1.19 & & 1.99 \\
\hline 27 & $14.9\left(\mathrm{CH}_{3}\right)$ & $14.9\left(\mathrm{CH}_{3}\right)$ & 1.11 & & 1.93 \\
\hline 28 & 181.1 (C) & $179.2(\mathrm{C})$ & - & & $1.59 ; 1.76$ \\
\hline 29 & $109.8\left(\mathrm{CH}_{2}\right)$ & $110.2\left(\mathrm{CH}_{2}\right)$ & $4.79 ; 4.96$ & $4.96 ; 4.79 ; 1.80$ & 1.80 \\
\hline 30 & $19.4\left(\mathrm{CH}_{3}\right)$ & $19.5\left(\mathrm{CH}_{3}\right)^{-}$ & 1.80 & $4.79 ; 4.96$ & $4.79 ; 4.96$ \\
\hline
\end{tabular}


Interpretation of the observed NOE enhancements suggests a structure for $\mathbf{2}$ as shown in Figure 2 that shows all protons mentioned above in 1,3-diaxial interaction.

After the interpretation of the NOE enhancements we were able to identify carbons 18 and 19 in the HETCOR spectrum. The proton at $\delta 2.40(\mathrm{H}-18)$ correlates with the carbon at $\delta 49.9$, and the proton at $\delta 3.71(\mathrm{H}-19)$ correlates the carbon at $\delta 52.1$. To assign carbons $\mathrm{C}-15$ and C-21, the proton at $\delta 2.53(\mathrm{H}-13)$ was irradiated and the NOE enhancement was observed on the protons at $\delta 1.57$ (Ha$15)$ and 1.03 (H-26). Those protons are on 1,3-diaxial positions with respect to H-13 (see Figure 2). The HETCOR spectrum indicated the correlation between the proton at $\delta 1.57(\mathrm{H}-15)$ and the carbon at $\delta 28.8$. The carbon at $\delta 30.3$, that showed no correlation, must be $\mathrm{C}-21$.

The complete assignments for the ${ }^{1} \mathrm{H}$ and ${ }^{13} \mathrm{C}$ NMR signals, as well the ${ }^{1} \mathrm{H} \mathrm{x}{ }^{1} \mathrm{H}$ and ${ }^{13} \mathrm{C} \mathrm{x}{ }^{1} \mathrm{H}$ correlations of 2 are reported in Table 2.

Table 2. ${ }^{13} \mathrm{C}(75.5 \mathrm{MHz})$ and $2 \mathrm{D}$ NMR data of platanic acid (2) in pyridine- $\mathrm{d}_{5}$

\begin{tabular}{|c|c|c|c|}
\hline $\mathrm{C}$ & $\delta^{13} \mathrm{C}(\mathrm{DEPT})$ & $\begin{array}{c}\text { HETCOR } \\
\left({ }^{13} \mathrm{Cx}^{1} \mathrm{H}\right) \delta^{1} \mathrm{H}\end{array}$ & $\begin{array}{l}\operatorname{COSY}\left({ }^{1} \mathrm{Hx}^{1} \mathrm{H}\right) \\
\left({ }^{2} J,{ }^{3} J \text { and }{ }^{4} J\right)\end{array}$ \\
\hline 1 & $39.3\left(\mathrm{CH}_{2}\right)$ & $0.94 ; 1.58$ & $1.58 ; 0.94 ; 1.86$ \\
\hline 2 & $28.4\left(\mathrm{CH}_{2}\right)$ & 1.86 & $0.94 ; 1.58 ; 3.46$ \\
\hline 3 & $78.2(\mathrm{CH})$ & 3.46 & 1.86 \\
\hline 4 & $39.6(\mathrm{C})$ & - & - \\
\hline 5 & $55.9(\mathrm{CH})$ & 0.79 & 1.39 \\
\hline 6 & $18.8\left(\mathrm{CH}_{2}\right)$ & 1.55 & - \\
\hline 7 & $34.8\left(\mathrm{CH}_{2}\right)$ & 1.39 & 0.79 \\
\hline 8 & $41.1(\mathrm{C})$ & - & - \\
\hline 9 & $50.9(\mathrm{CH})$ & 1.35 & - \\
\hline 10 & 37.8 (C) & - & - \\
\hline 11 & $21.2\left(\mathrm{CH}_{2}\right)$ & 1.39 & - \\
\hline 12 & $27.8\left(\mathrm{CH}_{2}\right)$ & 1.97 & 2.53 \\
\hline 13 & $37.6(\mathrm{CH})$ & 2.53 & $1.97 ; 2.30$ \\
\hline 14 & 42.7 (C) & - & - \\
\hline 15 & $28.8\left(\mathrm{CH}_{2}\right)$ & $1.57 ; 2.30$ & - \\
\hline 16 & $32.4\left(\mathrm{CH}_{2}\right)$ & $1.61 ; 2.62$ & $2.62 ; 1.61$ \\
\hline 17 & $56.6(\mathrm{C})$ & - & - \\
\hline 18 & $49.9(\mathrm{CH})$ & 2.40 & 3.71 \\
\hline 19 & $52.1(\mathrm{CH})$ & 3.71 & 2.40 \\
\hline 20 & $212.0(\mathrm{C})$ & - & - \\
\hline 21 & $30.3\left(\mathrm{CH}_{2}\right)$ & $1.28 ; 1.83$ & $1.83 ; 1.28$ \\
\hline 22 & $37.5\left(\mathrm{CH}_{2}\right)$ & $1.63 ; 2.23$ & $2.23 ; 1.63$ \\
\hline 23 & $28.7\left(\mathrm{CH}_{3}\right)$ & 1.23 & - \\
\hline 24 & $16.4\left(\mathrm{CH}_{3}\right)$ & 0.82 & - \\
\hline 25 & $16.4\left(\mathrm{CH}_{3}\right)$ & 1.02 & - \\
\hline 26 & $16.4\left(\mathrm{CH}_{3}\right)$ & 1.03 & - \\
\hline 27 & $14.9\left(\mathrm{CH}_{3}\right)$ & 1.10 & - \\
\hline 28 & $179.1(\mathrm{C})$ & - & - \\
\hline 29 & $29.7\left(\mathrm{CH}_{3}\right)$ & 2.24 & - \\
\hline
\end{tabular}

aChemical shifts on $\delta$ scale (ppm) from TMS.

\section{Experimental}

\section{General}

Mps: uncorr. IR: KBr pellet; EIMS: $70 \mathrm{eV}$; ${ }^{1} \mathrm{H}(300$ $\mathrm{MHz})$ and ${ }^{13} \mathrm{C}(75,5 \mathrm{MHz}) \mathrm{NMR}$ spectra were obtained in pyridine- $\mathrm{d}_{5}$ with TMS as internal reference; CC: silica gel 60 (70-230 mesh) and silica gel 60 (230-400 mesh); TLC: silica gel F254 (0.25 $\mathrm{mm}$ in thickness).

\section{Plant material}

Leaves and stems of the plant were collected in September 1996, at the edge of Paraná river, Porto Rico city, State of Paraná, Brazil and identified by Dr. Graziela Maciel Barroso, Jardim Botânico do Rio de Janeiro and Dr. Lucia Elena Soares e Silva, Universidade Federal de Brasilia. A voucher specimen (HUM 2163) was kept at the herbarium of the Biological Department of the Universidade Estadual de Maringá.

\section{Isolation}

Air-dried and powdered leaves and stems (920 g) of $E$. moraviana Berg., were extracted with $95 \%$ aq. EtOH $(18 \mathrm{~L})$ at room temp. The combined EtOH extracts were concd in vacuum and after lyophilization yielded $84 \mathrm{~g}$ of crude ethanolic extract. The crude ethanolic extract was partitioned with n-hexane $(900 \mathrm{~mL})$, chloroform $(500 \mathrm{~mL})$, ethyl acetate $(500 \mathrm{~mL})$ and $\mathrm{n}$-butanol $(500 \mathrm{~mL})$, yielding $11.7 \mathrm{~g}(32 \%), 27.3 \mathrm{~g}(32.5 \%), 8.2 \mathrm{~g}(9.8 \%)$ and $20.4 \mathrm{~g}(24.3 \%)$ respectively. Part of the chloroformic fraction $(6.0 \mathrm{~g})$ was subjected to CC on silica gel (101 g) and eluted with different ratios of n-hexane and EtOAc. The appropriate frs (monitored by TLC analysis) were combined resulting in 11 frs. Frs 69, eluted with n-hexane-EtOAc $(4: 1,2: 3)$ afforded ppts, which were purified by recristalization on $\mathrm{MeOH}$ to give betulinic acid (603 $\mathrm{mg}-10 \%)$. Fr. 10 (763.4mg) was subjected to $\mathrm{CC}$ on silica gel, eluted with n-hexane, n-hexane$\mathrm{CHCl}_{3}(1: 1), \mathrm{CHCl}_{3}, \mathrm{CHCl}_{3}$-EtOAc (1:1), EtOAc, EtOAc$\mathrm{MeOH}(1: 1)$ and $\mathrm{MeOH}$. The frs $\mathrm{CHCl}_{3}$-EtOAc $(1: 1)$ afforded ppts, which by recristalization on $\mathrm{CHCl}_{3}-\mathrm{MeOH}$ gave $6 \alpha$-hydroxybetulinic acid (1) (30 mg-3.9\%). The combined frs n-hexane and n-hexane- $\mathrm{CHCl}_{3}$ (1:1) (571mg) were subjected to repeated $\mathrm{CC}$ on silica gel, eluted with nhexane- $\mathrm{CHCl}_{3}$ mixts, and flash $\mathrm{CC}$ on silica gel, eluted with $\mathrm{CHCl}_{3}-\mathrm{MeOH}$ mixts of increasing polarity to give platanic acid (2) (25 mg-4.3\%). The n-hexane fraction (4.4 g) was refractionated successively by $\mathrm{CC}$ on silica gel, eluted with n-hexane-EtOAc mixts of increasing polarity which afforded $\beta$-sitosterol $(20.5 \mathrm{mg}-0.5 \%)$ and betulinic acid $(180 \mathrm{mg}-$ $4.0 \%)$.

6 $\alpha$-hydroxybetulinic acid (1): White crystals, mp 285$288^{\circ}$. IR $v_{\max } / \mathrm{cm}^{-1}: 3454,1685,1639,1038$ and 879 (KBr). EIMS m/z (rel. int.): 472 [M]॰ (0.5), 454 (2.9), 436 (3.7), 248 (10.9), 220 (3.9), 219 (5.6), 207 (11.3), 203 (14.9), 189 (25.8), 187 (66.9), 175 (17.5) and 43 (100). ${ }^{1} \mathrm{H}$ NMR (300 MHz, pyridine-d $\left.\mathrm{d}_{5}\right): \delta 0.96(3 \mathrm{H}, \mathrm{s}, \mathrm{H}-25), 1.11$ 
(3H, s, H-27), 1.19 (3H, s, H-26), 1.45 (3H, s, H-24), 1.80

(3H, s, H-30), 2.01 (3H, s, H-23), 3.60 (1H, m, H-3), 4.35

(1H, dt, $J 10.4$ and $3.8 \mathrm{~Hz}, \mathrm{H}-6), 4.79$ (1H, brs, H-29), and 4.96 (1H, d, J 2,3 Hz, H-29).

\section{Acknowledgements}

The authors thanks CAPES and CNPq for schoolarships (I. L. and J. L. B. P.). We also thank Dr. M. C. de Souza for support in the plant collection, Dr. G. M. Barroso (Jardim Botânico do Rio de Janeiro) and Dr. L. E. Soares e Silva (Universidade Federal de Brasilia) for the identification of the plant material.

\section{References}

1. Legrand, C. D.; Klein, R. M. Mirtaceas in Flora Ilustrada Catarinense (Reitz, P. R., ed), I parte, 1969, p 63 Herbário Barbosa Rodrigues, Itajaí - SC.

2. Schmeda-Hirschmann, G.; Theoduloz, C.; Franco, L.; Ferro, E. B.; Arias, A.R. J. Ethnopharmacol. 1987, 21, 183.

3. Mitscher, L. A.; Wu, W.; Beal, J. L. Lloydia 1973, $36,422$.

4. Slowing, K.; Söllhuber, M.; Carretero, E.; Villar, A. Phytochemistry 1994, 37, 255.
5. Lee, M.; Nishimoto, S.; Yang, L.; Yen, K.; Hatano, T.; Yoshida, T.; Okuda, T. Phytochemistry 1997, 44, 1343.

6. Henriques, A. T.; Sobral, M. E.; Cauduro, A. D.; Schapoval, E. E. S.; Bassani, V. L. J. Essent. Oil Res. 1993, 5, 501.

7. Goulart, M. O. F.; Sant'Ana, A. E.; Lima, R. A.; Cavalcante, S. H. Quim. Nova 1993, 16, 95.

8. Fujioka, T.; Kashiwada, Y. J. Nat. Prod. 1994, 57, 243.

9. Yasukawa, K.; Takido, M.; Matsumoto, T.; Takeuchi, M.; Nakagawa, S. Oncology 1991, 48, 72.

10. Bringmann, G.; Saeb, W.; Assi, L. A.; François, G.; Narayanan, KA.S.S.; Peters, K.; Peters, E. M. Planta Med. 1997, 63, 255.

11. Recio, M. C.; Giner, R. M.; Manez, S.; Gueho, J.; Julien, H. R.; Hostettmann, K.; Rios, J. L. Planta Med. 1995, 61, 9.

12. Mahato, S. B.; Kundu, A. P. Phytochemistry 1994, 37, 1517.

13. Siddiqui, S.; Hafeez, F.; Begum, S.; Siddiqui, B. S. J. Nat. Prod. 1988, 51, 229.

14. Peng C.; Bodenhausen, G.; Qiu, S.; Fong, H. H. S.; Farnsworth, N. R.; Yuan, S.; Zheng, C. Magn. Reson. Chem. 1998, 36, 267.

15. Budzikiewicz, H.; Wilson, J. M.; Djerassi, C. J. Am. Chem. Soc. 1963, 85, 3688.

16. Bilia, A. R.; Morelli, I. J. Nat. Prod. 1996, 59, 297.

Received: July 11, 2000

Published on the web: February 15, 2001 